\title{
The Effect of Suplementation Chlorella Vulgaris on Feed to Albumin Levels in Serum Nilem Fish (Osteochilus vittatus)
}

\author{
Kiki Siti Zakiah, Sorta Basar Ida Simanjuntak, Eko Setio Wibowo \\ Faculty of Biology, Jenderal Soedirman University \\ Jalan dr. Suparno no. 63 Purwokerto 53122 \\ email : Kikisitizakiah5@gmail.com
}

Rekam Jejak Artikel:
Diterima : $21 / 11 / 2019$
Disetujui : 24/10/2020

\begin{abstract}
Immunostimulant is a substance that is capable of increasing the mechanism of non-specif immune response of fish one of them is by adding Chlorella vulgaris extract to the feed. Th research objective is to determine the influence of Chlorella vulgaris supplementation on total bloc albumin in nilem fish. This research was conducted by sampling method consisting of 5 treatmen with further 4 replications. The treatments were feed supplementation of 0 g.kg-1 2 g.kg-1, 3 g.kg $4 \mathrm{~g} \cdot \mathrm{kg}^{-1}$, and $6 \mathrm{~g} \cdot \mathrm{kg}^{-1}$. Independent and dependent variables were used in this research; th independent variable was the dose of Chlorella vulgaris in the feed and the dependent variable w: blood albumin concentration. The measuring of plasma albumin concentration was done using th Dyasis kit method with a spectrophotometer. The obtained data were then analyzed by ANOV $t$ followed by the Least Significant Difference (LSD) at the 95\% confidence level if there is a re: difference then followed by Tukey's test at the same confidence level. The results showed that th average value of serum albumin concentration of nilem fish from all treatments was between $4.27 \epsilon$ $-7.1826 \mathrm{~g} / \mathrm{dL}$. The normal albumin concentration was found in the treatment with a dose Chlorel vulgaris supplementation at 4 g.kg-1 of feed which was $4.77 \mathrm{~g} / \mathrm{dL}$. Meanwhile, the highe concentration was found from the dose Chlorella vulgaris supplementation at $3 \mathrm{~g} . \mathrm{kg}-1$ of fec which was $6.677 \mathrm{~g} / \mathrm{dL}$. Thus, it can be concluded that, Chlorella vulgaris supplementation in fe with different doses can increase the serum albumin concentration of nilem fish in normal range. Keywords: Albumin, Chlorella vulgaris, Nilem fish.
\end{abstract}

\section{INTRODUCTION}

Nilem is a freshwater fish commodity that has been widely cultivation. It has a very specific and savory taste compared to other freshwater fish because it contains sodium glutamate which may be caused by its eating habits of natural plankton feed, especially algae which grows due to pond fertilization (Cholik, 2005). Quality feed works as a primary energy source and improves the digestive system of fish, so that the growth and health are optimal. Information concerning the health status of cultivation nilem to prevent diseases caused by bacterial infections has been done by giving antibiotics. However, giving antibiotics can lead to problems. Antibiotics can trigger various pathogenic microbes to become resistant if their use is not in accordance with the dose due to lack of knowledge. Therefore, alternative feeds are needed to improve the growth and health of cultivation nilem fish by utilizing immunostimulant ingredients (Pratiwi et al., 2011).

One of the immunostimulants which is capable to increase the mechanism of non-specific immune response of fish is by adding Chlorella vulgaris to feed. The mechanism can improve growth performance and control disease by increasing fish immunity. In addition, it can stimulate the proliferation, differentiation and activation of lymphocytes to increase the ability of fish to fight foreign objects entering its body, so antibodies are produced (Simanjuntak et al., 2006).

$$
\text { Chlorella vulgaris contains proteins, }
$$
vitamins, minerals, fats, polysaccharides and other nutritional substances. These microalgae can be 
used both as supplement feed and as natural feed for fish. The protein content of Chlorella Vulgaris ranges between 51 - 58\% with various essential amino acids, making it good animal feed (Becker, 2007). Moreover, Chlorella vulgaris is best used as herbivorous animal feed as it can have positive effects on growth, immunological, and physiological performance due to its high protein content. Therefore, it is good to be used as a food supplement for fish. In addition, Chlorella vulgaris microalgae contain bioactive compounds Chlorella Growth Factor (CGF) and Chlorellin that work as antibiotics to improve fish health (Simanjuntak et al. . 2014).

Fish health conditions can be seen from changes in blood serum protein, one of which is albumin which is the highest plasma protein (about $60 \%$ ) and has various functions that are very important for health. Albumins work to form new cell tissue, accelerate the recovery of damaged body tissue, and maintain fluid balance in blood vessels (Sus et al., 2011).

Based on the description, the problem that arises is how is the change in serum albumin concentration of nilem fish treated by feeding Chlorella vulgaris supplement at different doses. Thus, the objectives of this research are: Knowing the effect of differences in the dosage of Chlorella vulgaris supplementation in feeds on serum albumin levels of nilem fish. Knowing the dosage of Chlorella vulgaris supplementation in the best feed in maintaining serum albumin levels.

\section{MATERIALS AND METHODS}

The material were used are ikan nilem (Osteochilus vittatus), Chlorella vulgaris powder, Feed commercial and kit Dyasis albumin. The laboratory equipment will be used are ponds measuring $1 \mathrm{~m} \times 1 \mathrm{~m}$ along with aerators, cameras, analytical scales, reaction tubes, reaction tube rack, cuvette, plastick ziplock, millimeter block, preparation tray, $1 \mathrm{~mL}$ syringe, eppendorf, centrifugator, $10 \mu \mathrm{L}$ micropipette $-100 \mu \mathrm{L}, 100 \mu \mathrm{l}$ - $1000 \mu 1$ micropipette, blue tip, spectrophotometer, and stationery.

The research was conducted for 56 days, from June to August 2019. The location of research was at the Experiment Station D3 Fisheries Resource Management Program, Laboratory of Animal Physiology, Faculty of Biology, Jenderal Soedirman University.

This research used Completely Randomized Design with five treatments and four replications. The observed parameters were the total albumin in nilem fish (Osteochilus vittatus) and the interaction of the Chlorella vulgaris dose on total blood albumin in nilem fish (Osteochilus vittatus). The total albumin in nilem fish (Osteochilus vittatus) was measured using the Diasys Kit. Random sampling as used to obtain the samples. The treatments tested consisted of:

P0U1 - P0U4= Nilem fish treated with a dose Chlorella vulgaris at $0 \mathrm{~g} . \mathrm{kg}^{-1}$ of feed

P1U1 - P1U4= Nilem fish treated with a dose Chlorella vulgaris at 2 g. $\mathrm{kg}^{-1}$ of feed

P2U1 - P2U4= Nilem fish treated with a dose Chlorella vulgaris at 3 g.kg-1 of feed

P3U1 - P3U4= Nilem fish treated with a dose Chlorella vulgaris at 4 g.kg-1 of feed

P4U1 - P4U4= Nilem fish treated with a dose Chlorella vulgaris at $6 \mathrm{~g} \cdot \mathrm{kg}^{-1}$ of feed

The treatments of P0U1, P1U1, P2U1, P3U1 dan P4U1 were replicated four times to obtain twenty unit of treatments. 
The variables used in the research were the independent and the dependent variables. The independent variable was the dose of feed of Chlorella vulgaris and the dependent variable was the change in the concentration of serum albumin of blood of nilem fish. Meanwhile, the parameter measured was serum albumin concentration.

\section{Procedures}

\section{Research Pond Preparation}

A pond with the size of $1 \mathrm{~m} \times 1 \mathrm{~m} \mathrm{x} 30 \mathrm{~cm}$ was cleaned and poured with 30 Liter of water.

\section{Supplementation Feed Preparation}

Chlorella vulgaris supplementation to commercial feed was carried out by the following procedures: $500 \mathrm{~g} \cdot \mathrm{kg}^{-1}$ commercial feed was placed in a plastic bag. At a dose of 0 , an amount of commercial feed of $500 \mathrm{~g} \cdot \mathrm{kg}^{-1}$ and not supplemented with Chlorella vulgaris because it acted as control. At a dose of 1, an amount of commercial feed of $500 \mathrm{~g} \cdot \mathrm{kg}^{-1}$ was placed in a plastic bag. Dried Chlorella vulgaris weighed 2 g. $\mathrm{kg}^{-1}$ was put in a beaker glass. Then, $75 \mathrm{ml}$ of water was added and dissolved until it became homogeneous. The solution was mixed to commercial feed in evenly spread manner. At a dose of 2, an amount of commercial feed of 500 g. $\mathrm{kg}^{-1}$ was placed in a plastic bag. Dried Chlorella vulgaris weighed 3 g. $\mathrm{kg}^{-1}$ was put in a beaker glass. Then, $75 \mathrm{ml}$ of water was added and dissolved until it became homogeneous. The solution was mixed to commercial feed in evenly spread manner. At a dose of 3, an amount of commercial feed of 500 g. $\mathrm{kg}^{-1}$ was placed in a plastic bag. Dried Chlorella vulgaris weighed $4 \mathrm{~g} . \mathrm{kg}^{-1}$ was put in a beaker glass. Then, $75 \mathrm{ml}$ of water was added and dissolved until it became homogeneous. The solution was mixed to commercial feed in evenly spread manner. At a dose of 4, an amount of commercial feed of 500 g. $\mathrm{kg}^{-1}$ was placed in a plastic bag. Dried Chlorella vulgaris weighed 6 g. $\mathrm{kg}^{-1}$ was put in a beaker glass.
Then, $75 \mathrm{ml}$ of water was added and dissolved until it became homogeneous. The solution was mixed to commercial feed in evenly spread manner. Then, all supplemented feed was dried in the sun. After the feed dried, it was left at room temperature and put in a jar which was tightly closed. Supplementation feed was given as much as $3 \%$ for 56 days per total body weight and was given 2 times a day and was ready to be tested on nilem fish.

\section{Nilem Fish Preparation}

160 nilem fish were placed in 20 ponds with a density of 8 fish per pond. The fish were acclimatized for a week to adapt to the environment before the treatments. During acclimatization, the fish were fed commercially twice a day.

\section{Sampling}

Nilem fish samples were taken from rearing tanks using a net. Blood sampling was done once after the nilem has been given treatments. The blood was taken with a $3 \mathrm{ml}$ syringe and collected using an eppendorf tube. It was ensured to be \pm 30 minutes minutes at a room temperature. The sample was centrifuged at $4000 \mathrm{rpm}$ for 20 minutes. Then, the supernatant in the form of blood serum was taken using a dropper pipette and moved to a new eppendorf tube.

\section{Data Collecting}

Data collection on serum albumin was carried out after 56 days treatments of Chlorella vulgaris feed supplementation with different dosages - 0 g. $\mathrm{kg}^{-1}, 2$ g. $\mathrm{kg}^{-1}, 3$ g. $\mathrm{kg}^{-1}, 4$ g. $\mathrm{kg}^{-1}, 6$ g. $\mathrm{kg}^{-1}$. The measuring was done at the Laboratory of Animal Physiology, Faculty of Biology of Jenderal Soedirman University

\section{Serum Albumin}

The blood serum albumin of nilem fish was examined using a photometer with the Diasys Kit method with the following specification: 
wavelength $\mathrm{Hg} 546 \mathrm{~nm}$; optical path $1 \mathrm{~cm}$; temperature : $20-25^{\circ} \mathrm{C} / 37^{\circ} \mathrm{C}$; and measurment againt reagent blank

\section{Serum Preparation}

Blood samples were put into a centrifuge tube and then centrifuged for about 20 minutes at $4000 \mathrm{rpm}$. The blood serum was taken and put in a test tube.

\section{Blank Absorbent Measurement}

Prepared equipments and materials were piped $10 \mu \mathrm{L}$ aquadest, and then put into cuvette, then subsequently added $1000 \mu \mathrm{L}$ of Albumin reagent. It was then incubated at $25^{\circ} \mathrm{C}$ for 10 minutes. The absorbent was then measured on a spectrophotometer with a wavelength of $546 \mathrm{~nm}$.

\section{Standard Absorbent Measurement}

Prepared equipments and materials were piped $10 \mu \mathrm{L}$ aquadest, and then put into cuvette, then subsequently added $1000 \mu \mathrm{L}$ of Albumin reagent. It was then incubated at $25^{\circ} \mathrm{C}$ for 10 minutes. The absorbent was then measured on a spectrophotometer with a wavelength of $546 \mathrm{~nm}$.

\section{Sample Absorbent Measurement}

Prepared equipments and materials were piped $10 \mu \mathrm{L}$ aquadest, and then put into cuvette, then subsequently added $1000 \mu \mathrm{L}$ of Albumin reagent. It was then incubated at $25^{\circ} \mathrm{C}$ for 10 minutes. The absorbent was then measured on a spectrophotometer with a wavelength of $546 \mathrm{~nm}$. The albumin concentration can be calculated using the following equation:

Albumin Concentration (g/dl):

$$
\text { Alb. Conc. }=\frac{\text { A sampel }}{A S T D} X \text { Conc. of STD (g/dl) }
$$

Note:

A sample $=$ Sample absorbent

A STD $=$ Standard absorbent

\section{Data Analysis}

The obtained data were then analyzed by ANOVA, followed by the Least Significant Difference (LSD) at the 95\% confidence level.

\section{RESULT AND DISCUSSION}

The measuring of serum albumin concentration is needed to see the immune response in nilem fish. The average value of serum albumin concentration of nilem fish from all treatments was between 4.2761 - $7.1826 \mathrm{~g} / \mathrm{dL}$. The normal albumin concentration was found in the treatment 4 g. $\mathrm{kg}^{-1}$ Chlorella vulgaris supplementation which was $4.77 \mathrm{~g} / \mathrm{dL}$. Meanwhile, the highest concentration was found from the supplementation of Chlorella vulgaris at $3 \mathrm{~g} \cdot \mathrm{kg}^{-1}$ feed which was $6.677 \mathrm{~g} / \mathrm{dL}$. The complete results are presented in Figure 1.

The results of the analysis of Turkey's further tests with the same confidence level showed significant difference between studies during the study $(\mathrm{P}<0.05)$. Based on the analysis results of Tukey further tests with a $95 \%$ confidence level, it showed that P2 treatment (supplementation dose 3g.kg-1) the highest amount of albumin concentration compared to P0 (without supplementation) and P3 treatment (4g.kg-1 supplementation dose). Fugure 1. shows that the P2 and P4 treatments were not significantly different, so that economically, $2 \mathrm{~g} . \mathrm{kg}^{-1}$ of Clorella vulgaris supplementation in the feed can be applied. According to Rehulka et al. (1993) ie the normal range of total protein values is 6-8 g.dLsch1 , albumin values 3.5 - 5 g.dL-1, globulin is 1.5 2.5 g.dL- 1 and the ratio the $\mathrm{A} / \mathrm{G}$ ratio is $0.7-1.18$ g.dL-1. The A / G ratio is best in the range of 0.71.18 g.dL-1, so the results of the albumin ratio calculation on day 56 determine the dose of Chlorella vulgaris supplementation 4 g.kg-1 in the feed which reaches $4.77 \mathrm{~g}$. $\mathrm{dL}-1$ is the best albumin ratio because it collects an albumin value of 3.5 - 5 g.dL-1 in the normal albumin ratio rating. 


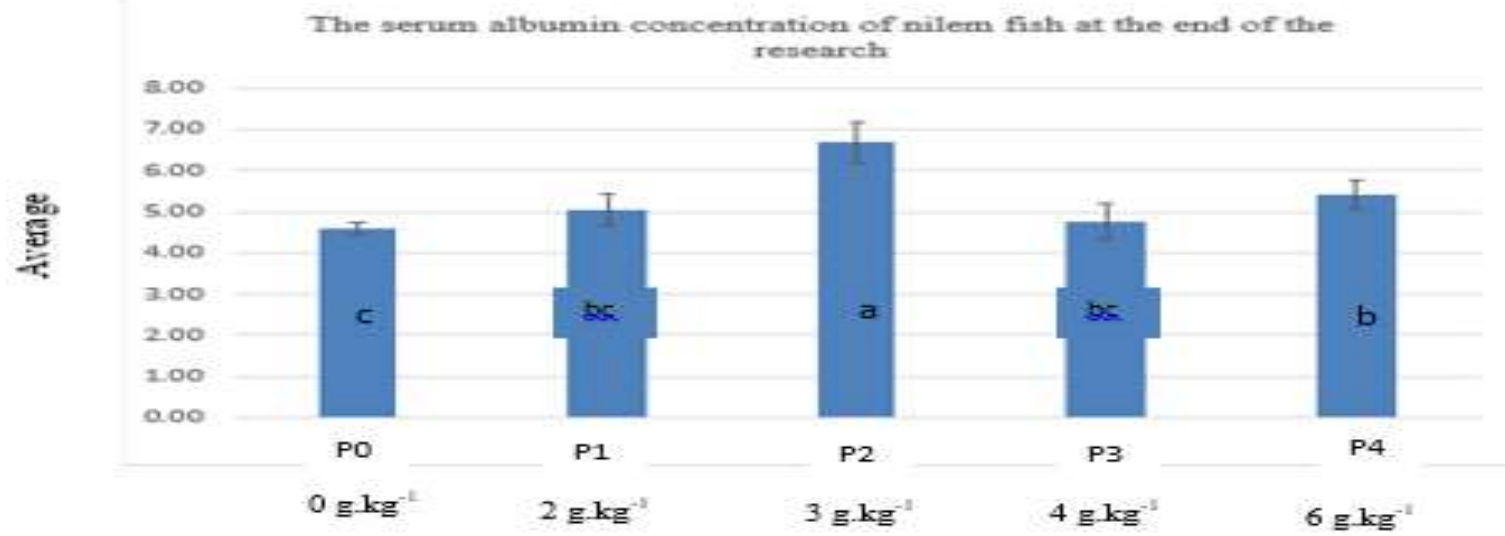

Figure 1. Grafik The Serum Concentration of Nilem Fish

According to Hoseini et al. (2018), this result can be used as an indication of an increase in fish health. Improved fish health status can be influenced by feeding the Chlorella vulgaris supplementation feed. Increased concentrations of fish blood protein (albumin) can be evidence of increased in fish body resistance (antioxidant protein and enzyme activity) against exposure to disease infections.

The results of this research indicate that supplementation of Chlorella vulgaris in feed can increase fish serum albumin concentration. This will lead to improved immune system of fish. Increased serum albumin concentration through Chlorella vulgaris supplementation feed, according to Guardiola et al. (2018) and Kumar et al. (2017), can be caused by various nutrients and active compounds such as peroxade, $\beta$-carotene and phycocyanin contained in Chlorella vulgaris. These active compounds can boost the fish's immune system because it can increase the fish's immune response to toxins in the body.

According to Kumar et al. (2017) and Guardiola et al. (2018), measurement of blood protein can be used as an indicator of fish health. Albumin is a protein that plays a role in the transportation of nutrients in the circulatory system and osmotic regulation. Moreover, globulin can be used as an indicator of fish immunity. An increase in total protein, both albumin and globulin, can increase non-specific immune responses (El Asely et al., 2014). An increase in the total dose of protein and albumin by supplementing Chlorella

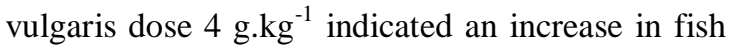
immune response (Morris et al., 2011).

According to Yaganeh et al. (2017), phycocyanin and $\beta$-carotene from Chlorella vulgaris will promote the regeneration of cell tissue growth and the division of white blood cells (leukocytes). This mechanism stimulates leukocyte production as well as phagocytic activity and formation of lymphocytes that produce antibodies. Phycosianin and $\beta$-carotene also have gastrointestinal microflora activity in gamma irradiation by inducing hematopoiesis called blood cell formation. In the end, it will increase the value and number of blood cells. This extract, if given to animals that have tumor disease, can significantly stimulate the hemopoletic stem cell colonies in bone fronds and produce a longer survival period. Increased value and number of blood cells will have an effect on increasing the concentration of total protein, albumin and globulin.

The total amounts of protein, albumin, and globulin have an important role in the immune system of animals (Yang et al., 2014). Increased 
concentrations of protein, albumin and globulin will associate well with the fish's innate immune system (Akrami et al., 2015). Albumin is a protein that can easily be found and can act as a connecting protein. It is a protein that works as a regulator of blood osmotic pressure and serves as a transport medium of metabolic products (fatty acids, hormones, bilirubin). In addition, albumin in fish can play a role in the immune system (Guardiola, et al., 2018, Kumar et al., 2017).

Albumin is a large part of the ionic protein found in vertebrate animals. The amount of albumin includes $52 \%$ of the total plasma protein. Albumin has a role in the transportation of endogenous and xenobiotic ligands. In addition, it has an important role in the osmotic system as it preserves fish health (Silva et al., 2015). Research conducted by Adel et al., (2016) stated that there is an increase in haematological responses and biochemical concentrations of blood of Rainbow trout (Oncorhynchus mykiss) fed with Chlorella vulgaris supplemented with $10 \%$ of the feed weight. The increase is caused by the content of the active ingredient phycocyanin and high iron content of Chlorella vulgaris. Moreover, Adel et al. (2016) stated there was an increase in the number of leukocytes and albumin concentrations in Great sturgeon fish (Huso huso) which were given Chlorella vulgaris supplementation feed by $10 \%$. The increase in the number of leukocytes and albumin concentration made the fish's health status improved. The response shown can increase the immune response and growth in these fish. These results are in line with research conducted by Siringi et al. (2016). Based on the research, feed containing Chlorella vulgaris can improve the physiological condition of fish and increase fish growth and immunity

\section{CONCLUSION}

Based on result and discussion, the following conclusions are Chlorella vulgaris supplementation in feed with different doses can increase the serum albumin concentration of nilem fish in normal range. Economically, Chlorella vulgaris supplementation at a dose of $2 \mathrm{~g} \cdot \mathrm{Kg}^{-1}$ in feed can be applied

\section{Suggestion}

The suggestion for further research is that in fish cultivation, it is necessary to use feed supplemented with Chlorella vulgaris in order to increase fish immunity.

\section{REFERENCES}

Abdel-Tawwab, Mohsen dan Mohammad H. Ahmad. 2009. Live Spirulina (Arthrospira platensis) as a growth and immunity promoter for Nile tilapia, Oreochromis niloticus (L.), challenged with pathogenic Aeromonas hydrophila. Aquaculture Research.(4)

Adel, Milad, Sakineh Yeganeh, Maryam Dadar, Masahiro Sakai, Mahmoud AO Dawood. 2016. Effects of dietary Spirulina platensis on growth performance, humoral and mucosal imune responses and disease resistance in juvenile great sturgeon (Huso huso Linnaeus, 1754). Fish and Shellfish Imunology. 2(56): 436-444

Agustin P.K.A., Sri H., Alfabetian H.C.H. 2017. Pengaruh Ekstrak Temulawak Pada Pakan Sebagai Imunostimulan Pada Ikan Tawes (Puntius Javanicus Dengan Uji Tantang Bakteri. Tembalang. Semarang

Akrami Raza, Ahmad Gharaei, Majid Razeghi Mansour, Ali Galeshi. 2015. Effects of dietary onion (Allium cepa) powder on growth, innate immune response and hematoebiochemical parameters of beluga (Huso huso Linnaeus, 1754) juvenile. Fish \& Shellfish Immunology. 2(45); 828-834.

Becker, E.W., 2007. Microalgae as a source of protein. Biotechnol. Adv., 25(2), 207-210.

Cholik, F., Ateng GJ., R. P. Purnomo \& Ahmad Z. 2005. Akuakultur Tumpuan Harapan Masa Depan Masyarakat Perikanan Nusantara 
dan Taman Akuarium Air Tawar. Jakarta: Viktoria Kreasi Mandiri.

Florensia S. P., Tri R.S., Munifatul I. 2015. Potensi Chlorella vulgaris Beijerinck Dalam Remidiasi Logam Berat Cd Dan Pb Skala Labolatorium. 16 (2). Tembalang. Semarang

Ginanjar, A. 2011. Pengaruh Bobot Ikan Nilem (Osteochilus hasselti) Terhadap Tingkat Konsumsi Perifiton. Fakultas Perikanan dan Ilmu Kelautan Universitas Padjadjaran, Bandung.

Guardiola FA, Bahi A, Esteban MA. 2018. Effects of dietary administration of fenugreek seeds on metabolic parameters and immune status of gilthead seabream (Sparus aurata L.), Fish and Shellfish Immunology. (23) : 3440.

Hiroko O., Takeo N., Yuki K., Yuki. 2017. Serum albumin levels and their correlates among individuals with motor disorders at five institutions in Japan. Kyoto University School of Public Health. Japan

Hoseini Seyyed Morteza, Morteza Yousefi, Seyed Hossein Hoseinifar, Hein Van Doan. 2018. Effects of dietary arginine supplementation on growth, biochemical, and immunological responses of common carp, (Cyprinus carpio L.), stressed by stocking density. Journal Aquaculture.

Kaslow JE. 2010. Analysis of Serum Protein. Santa Ana: 720 North Tustin Avenue Suite 104, CA

Kumar S, Raman RP, Prasad KP, Srivastva PP, Kumar S, Rajendran KV. 2017. Modulation of innate immune responses and induction of oxidative stress biomarkers in Pangasianodon hypophthalamus following an experimental infection with dactylogyrid monogeneans. Fish and Shellfish Immunology. (34): 384-890.

Liu L., Georg P., Dong W. 2016. Extracellular Metabolites from Industrial Microalgae and Their Biotechnological Potential. China University of Technology. China

Matheus N. 2013. The Isolation of Albumin and Characteristics of Molecular Weight from Extraction Result by Steaming of Fish Gabus (Ophiocephalus striatus). Fakultas Pertanian Universitas Yudharta Pasuruan. Jawa Timur
Merlyn D., Manurung., Reiny A., Tumbo., Henneke P., Deiske A. S., Remy E. P., Mangindaan. 2019. Pemanfaatan Ekstrak Kasar Spons Untuk Meningkatkan Pertumbuhan Dan Respon Imun Non Spesifik Ikan Nila (Oreochromis niloticus). ISSN 2302-3589. Universitas Sam Ratulangi. Manado

Pratiwi., Rita R., Yayat D. 2011. Pengaruh Tingkat Pemberian Pakan Terhadap Laju Pertumbuhan Dan Deposisi Logam Berat Pada Ikan Nilem Di Karamba Jaring Apung Waduk IR. H. Djuanda. ISSN 0853-2523. Fakultas Perikanan dan Ilmu Kelautan Kampus Jatinangor. Bandung

Řehulka, J. (1993). Erythrodermatitis in Carp (Cyprinus carpio L.): An Electroforetic Study of Blood Serum Protein Fraction Levels. Acta Veterinaria Brno, 62(3-4): 187-197.

Royan, M. R., Khomaruddin., M. D. ArifidanMinto. 2010. Chlo-Juice (Jus Chlorella) Sebagai Minuman Multivitamin Berkhasiat, Berkalsium, Dan BerproteinTingi Serta Sebagai Peluang Usaha Multiprofit. PKMK. UniversitasAirlangga. Surabaya. $16 \mathrm{pp}$

Salasia, Oktavia, S.I., Hariono, B. 2010. Patologi Klinik. Samudra Biru. Yogyakarta.

Simanjuntak, S.B.I., Edy, Y., Farida, N, H. 2006.Pengaruh Penyuplemenan Spirulina Dalam Pakan Terhadap Hematologis Ikan Nilem (Osteochilus hasselti C.V). Universitas Jenderal Soedirman. Purwokerto. Indonesian

Simanjuntak, S.B.I., Soedibya, P.H.T., \& Wibowo, E.S. 2014. Growth performance of gurami (Osphronemus gouramy Lac.) the given phytoplankton Spirulina platensis and Chlorella vulgaris: 157-165.

Silva, Dilson., Celia Martins Cortez., Natalia P. Nogueira., dan Frederico Freire da Cunha Bastos. 2015. Purification and physicochemical study of serum albumins of two neotropical fish species from the $\mathrm{Sa}^{2}$ Francisco River Bassin, Brazil. Biota Neotropica. : 15 (3).

Siringi, J.O., Kang ombe, J., Jere WW., Mtethiwa A.H. 2016. Effect of dietary spirulina on growth, haematological factors and survival of Oreochromis shiranus challenged with Aeromonas hydrophila. Ruforum. 3(14) 
Sus D. W., Anita E., Herlina. 2011. Profil Protein Total Albumin Dan Globulin Pada Ayam Broiler Yang Di beri Kunyit, Bawang Putih Dan Zink (Zn). ISSN 0853-4217 Vol. 16 No.3. Patologi Fakultas Kedokteran Hewan, Institut Pertanian Bogor. Bogor.

Siti Y, R., Anhar S., Suradi W. S. 2014. Aspek Pertumbuhan Dan Reproduksi Ikan Nilem (Osteochilus haselti) Di Perairan Rawa Pening Kecamatan Tuntang Kabupaten Semarang. Universitas Diponegoro Tembalang, Semarang, Jawa Tengah
Yageneh, Sakineh. Mahdi Teomori. 2015. Dietary effects of Spirulina platensis on hematological and serum biochemical parameters of rainbow trout (Oncorhynchus mykiss). Research in Veterinary Science.

Yang X, Guo J, Ye J, Zhang Y, Wang W. 2014. The effects of Ficus carica polysaccharide on immune response and expression of some immune-related genes in grass carp, Ctenopharyngodon idella, Fish and Shellfish Immunology. 